Article

\title{
Prototype Co-Pyrolysis of Used Lubricant Oil and Mixed Plastic Waste to Produce a Diesel-Like Fuel
}

\author{
Natacha Phetyim ${ }^{1}$ and Sommai Pivsa-Art ${ }^{2, *}$ \\ 1 Energy and Materials Engineering Program, Faculty of Engineering, Rajamangala University of Technology \\ Thanyaburi, Pathum Thani 12110, Thailand; nattacha.p@en.rmutt.ac.th \\ 2 Department of Materials and Metallurgical Engineering, Faculty of Engineering, Rajamangala University of \\ Technology Thanyaburi, Pathum Thani 12110, Thailand \\ * Correspondence: sommai.p@en.rmutt.ac.th; Tel.: +66-2549-4606
}

Received: 8 October 2018; Accepted: 29 October 2018; Published: 1 November 2018

check for updates

\begin{abstract}
The co-pyrolysis of used lubricant oil blended with plastic waste, namely high-density polyethylene (HDPE), polypropylene (PP), and polystyrene (PS), to produce a diesel-like fuel was studied. The proportions of the raw materials were optimized using laboratory scale pyrolysis at atmospheric pressure at a final temperature of $450{ }^{\circ} \mathrm{C}$ without a catalyst. The ratios of used lubricant oil (Oil) and plastic waste (Oil:HDPE:PP:PS) investigated were 50:30:20:0, 50:30:0:20, 50:0:30:20, and 50:30:10:10 by weight. It was found that the oil produced using an Oil:HDPE:PP:PS ratio of 50:30:20:0 exhibited most of the properties of standard diesel oil as specified by the Ministry of Energy (Thailand), except for its flash point, which was lower than the standard. Therefore, this proportion was utilized for the scaled-up testing in the co-pyrolysis prototype $(10 \mathrm{~kg} /$ day $)$. Three reactor temperature ranges (less than $400{ }^{\circ} \mathrm{C}, 400-425^{\circ} \mathrm{C}$, and $425-450{ }^{\circ} \mathrm{C}$ ) were studied, and the properties of the oil products were analysed. The oil products produced at $400-425{ }^{\circ} \mathrm{C}$ exhibited diesel-like fuel properties.
\end{abstract}

Keywords: co-pyrolysis; used lubricant oil; plastic waste; scale-up prototype

\section{Introduction}

Pyrolysis is an environmentally friendly method to recover hydrocarbon materials due to its good capacity and lower environmental impact. In 2015, the Pollution Control Department of the Ministry of Natural Resources and Environment reported that the amount of municipal solid waste (MSW) in Thailand had continuously increased to approximately 29.09 million tons, of which 13.6 million tons had been disposed. Of this, only 8.4 million tons were disposed of by appropriate methods, i.e., landfilling or incineration. However, about 7.09 million tons of MSW were disposed of through dumping on the ground or in the water, or by combustion in open air [1]. MSW or household waste can be separated into three parts: (1) combustibles such as textiles, paper, wood, and kitchen waste; (2) non-combustibles such as metal, ceramics, and glass; and (3) plastics. The plastic waste collected comprises a mixture of plastics, with major components such as polyethylene (PE), polypropylene (PP), polystyrene (PS), polyvinyl chloride (PVC), and polyethylene terephthalate (PET). In Thailand, hazardous mixed scrap waste comprising used lubricant oil, car batteries, and fluorescent tubes has been found throughout the country. For the pyrolysis of plastic waste, the co-existing hazardous waste must be sorted out. However, used lubricant oil with low hazardous material content can be thermally decomposed to small hydrocarbons. During the pyrolysis reactions of mixed plastic waste, PE and PP are converted into a mixture of paraffins and olefins, while PS is converted into aromatic monomers [2]. Therefore, mixtures of plastic waste containing PE, PP, and PS and used lubricant oil can undergo pyrolysis to produce oil and small hydrocarbons. 
The oil waste used in pyrolysis processes includes automotive engine oil, brake fluid, gear oil, and power steering fluid. These are mixed during collection and storage. The amount of lubricant oil used in automotive engines increases each year due to the increasing number of automobiles. The recycling of used lubricant oil into fuel oil or lubricant oil may be a suitable option for protecting the environment from hazardous waste, as the oil waste typically consists of a mixture of the base oil and additives, which have high concentrations of heavy metals, varnishes, gums, and asphaltic compounds [3]. Over $80 \%$ of waste lubricant oil consists of $C_{26}-C_{36}$ compounds, which means it contains a high amount of heavy paraffins [4]. Bhaskar et al. reported the catalytic thermal treatment of waste lubricant oil with silica-, silica-alumina-, and alumina-supported iron oxide catalysts at $400{ }^{\circ} \mathrm{C}$ and atmospheric pressure [5]. The $\mathrm{Fe} / \mathrm{SiO}_{2}$ catalyst decreased the sulfur content from 1640 to $90 \mathrm{ppm}$ and produced low molecular weight hydrocarbons by cracking the high molecular weight hydrocarbons. Lam et al. treated automotive engine oil using a microwave-induced pyrolysis process [6]. The results showed that both fresh and waste engine oil were composed mainly of linear and branched paraffins $(>85 \%)$, and that the long-chain hydrocarbons could be converted into more valuable compounds.

Co-pyrolysis techniques can provide valuable products through the disposal and conversion of plastic waste and other hydrocarbon sources. Waste lubricant oil is a good source of renewable resources because of its uniform composition. Waste plastic pyrolysis has low heat transfer and high viscosity of melting polymer. When lubricant oil is mixed with plastic waste, it can act as a solvent to decrease viscosity and improve heat transfer in the reactor [7]. An optimum reactor design must ensure both high heat transfer rates for fast heating of the polymer and reliable temperature control. The operational problems are related to the sticky nature of the fused plastic [8]. The optimization of conversion parameters such as the choice of catalysts, reactor design, pyrolysis temperature, and plastic-to-catalyst ratio play a very important role in the efficient processing of gasoline and diesel grade fuel [9]. Serrano et al. studied thermal cracking using a screw kiln reactor in two temperature zones ( 450 and $500{ }^{\circ} \mathrm{C}$ for the first and second zone, respectively) [10] and Low density polyethylene (LDPE) and lubricant oil base mixtures with compositions of 40:60, 50:50, 60:40, and 70:30 (\%wt.). In all cases, near-complete conversion (approximately $90 \%$ ) with a tendency range of $C_{1}-C_{40}$ hydrocarbons was achieved. The addition of waste motor oil to waste polyolefins not only increased the liquid yield, but also improved the properties of the liquid product, with greater naphtha and paraffinic contents in the products of the co-pyrolysis oil than in the products of the individual waste polyolefins [11]. However, the proportion of used lubricant oil in the oil/plastic waste blend cannot be more than $50 \%$ by raw material weight, because greater oil contents tend to produce oil products that are non-diesel-like [12,13]. Bartocci et al. [14] reported pyrolysis results of glycerol addition in pellet fuels while mixed with sawdust. They showed that the percent yield of gas was increased for the pellets using high glycerol content. The proportion of mixed materials presented a tendency to yield products in proportion to the raw materials mixture [15].

The co-pyrolysis reactors of used oil blended with plastic wastes with various design for a laboratory scale have been reported. Uçar et al. [11] reported their study on co-pyrolysis of individual and blended polyolefin wastes and motor oil waste at $500{ }^{\circ} \mathrm{C}$ in a fixed bed reactor. The amount of raw materials studied was $100 \mathrm{~g}$. Serrano et al. [10] reported thermal and catalytic cracking of a LDPE-lubricant oil base mixture in a continuous screw kiln reactor. A significant enhancement in the product output took place with increasing proportions of the lubricating oil base in the mixture. Miskolczi and Ateş [16] reported the co-pyrolysis of real municipal plastic waste (MPW) and MPW derived heavy oil (HO) mixtures in the stirred reactor by $750 \mathrm{~g}$ of raw materials and $500{ }^{\circ} \mathrm{C}$ as a final temperature. Breyer et al. [15] reported the co-pyrolysis lab scale experiments that were carried out in a $5 \mathrm{~L}$ batch reactor with spiral stirrer. Raw materials were the mass of mixture between plastic waste from landfill and used motor oil 412 and $574 \mathrm{~g}$ for each experiment. Kim et al. [17] reported a pyrolysis of mixture of waste of automobile lubricating oil (WALO) and PS. The pyrolysis reaction was carried out in the $1 \mathrm{~L}$ of stirred batch reactor, a sample mass of $300 \mathrm{~g}$ for all experiment runs, the temperature 
controlled the pyrolysis temperature in range of $300-500{ }^{\circ} \mathrm{C}$. Most previous works has been focused on a utilization of a stirred batch reactor for co-pyrolysis of used lubricant oil and plastic wastes because the process was simple design and used lubricant oil increasing heat transfer in the reactor.

The aim of this work is to apply a two-stage methodology for a prototype co-pyrolysis process for used lubricant oil blended with mixed waste plastics (HDPE, PP, and PS). The optimum proportion of feedstocks was determined at the laboratory scale, and then studied at the prototype scale in order to optimize the diesel-like oil products.

The novelty and relevance of this work are optimization of proportion of used lubricant oil and mixed plastic wastes. The pyrolysis products are focused on diesel properties and the design melting stage for control proportion of raw materials before feeding to the semi-batch reactor at cracking temperature.

\section{Materials and Methods}

\subsection{Materials and Sample Preparation}

The sample of waste lubricant oil was API SN 0W20 from the Thanyaburi Honda Cars Center (viscosity@100 ${ }^{\circ} \mathrm{C}: 9.12 \mathrm{cSt}$; flash point: $194{ }^{\circ} \mathrm{C}$; specific gravity: 0.878). The waste oil was dehydrated by heating at $110^{\circ} \mathrm{C}$ for $1 \mathrm{~h}$ with stirring at $200 \mathrm{rpm}$. The HDPE plastic waste samples were collected from drinking water bottles, the PP samples were collected from water cups, and the PS samples were food box packaging. All plastic waste was ground to a particle size of $5-7 \mathrm{~mm}$.

\subsection{Thermogravimetric Analysis}

The decomposition of the waste oil, HDPE, PP, and PS samples was monitored by thermogravimetric analysis (TGA) using a TG 209F3 instrument (NETZSCH, Selb, Germany). Samples of approximately $10 \mathrm{mg}$ of PP and HDPE and $5 \mathrm{mg}$ of PS were heated. The samples were maintained at ambient temperature $\left(32{ }^{\circ} \mathrm{C}\right)$ for $10 \mathrm{~min}$ and then linearly heated from $32{ }^{\circ} \mathrm{C}$ to $700{ }^{\circ} \mathrm{C}$ at a heating rate of $20^{\circ} \mathrm{C} / \mathrm{min}$ for $10 \mathrm{~min}$ with a nitrogen gas $\left(\mathrm{N}_{2}\right)$ flow rate of $20 \mathrm{~mL} / \mathrm{min}$.

\subsection{Pyrolysis Experiments}

- Laboratory Scale Pyrolysis

The lab-scale co-pyrolysis experiments were carried out in an unstirred batch reactor. The reactor consisted of a $1 \mathrm{~L}$ borosilicate glass vessel with a proportional-integral-derivative (PID) controller operated under nitrogen at atmospheric pressure. In each experiment, $350 \mathrm{~g}$ of raw materials were placed in the reactor, heated from room temperature to $450{ }^{\circ} \mathrm{C}$, and held at the final temperature of $450{ }^{\circ} \mathrm{C}$ for $4 \mathrm{~h}$ (Figure 1 ).

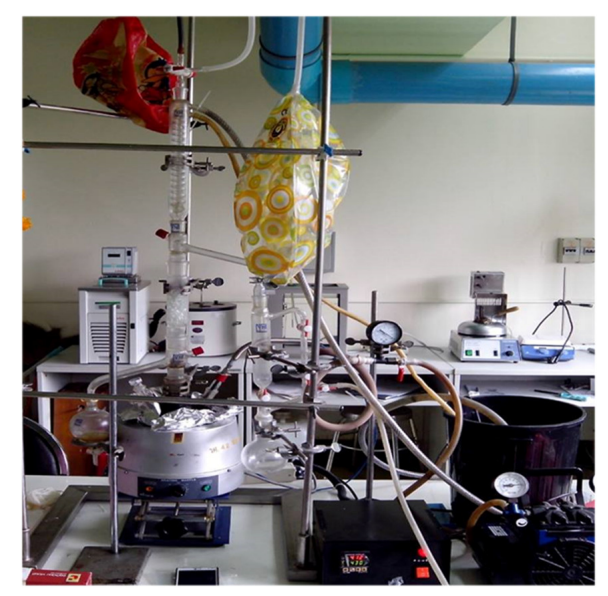

Figure 1. Laboratory scale pyrolysis process. 
- $\quad$ Proportions of Waste Lubricant Oil and Waste Plastics

The co-pyrolysis of used lubricant oil mixed with three types of waste plastic was studied using mixtures with proportions (Oil:HDPE:PP:PS) of 50:30:10:10, 50:30:20:0, 50:30:0:20, and 50:0:30:20 percent by weight. The reactor was operated for $4 \mathrm{~h}$ to ensure that the reaction was complete. The yield of oil products was determined by weighing the oil collected from vessels using a condenser, and the yield of solid products was determined by measuring the weight of the residue at the end of the reaction. The gaseous product yield was determined by mass balance, assuming that the total weight of all products was equal to the initial weight of the raw materials.

- Co-pyrolysis Prototype

The co-pyrolysis prototype setup is shown in Figure 2. Waste motor oil blended with HDPE, PP, and PS in a proportion of 50:30:20:0 percent by weight was used for co-pyrolysis with a final temperature of $450{ }^{\circ} \mathrm{C}$ for $80 \mathrm{~min}$ and without the addition of any catalyst. The waste oil $(5 \mathrm{~kg})$ was placed in a mixing tank and heated to $180^{\circ} \mathrm{C} .5 \mathrm{~kg}$ of plastic waste consisting of HDPE (3 kg) and PP ( $2 \mathrm{~kg})$ was melted into a homogenous phase, and then fed into the stirred reactor and heated to $300{ }^{\circ} \mathrm{C}\left(10^{\circ} \mathrm{C} / \mathrm{min}\right)$ under $0.5 \mathrm{bar}$ of nitrogen gas. The mixing tank and the reactor were made of 304 stainless steel, and both had a capacity of $20 \mathrm{~L}$. The internal temperature at the top and bottom of the reactor vessel was measured using a thermocouple, and the jacket temperature was controlled by a PID controller. Gases from the reactor were driven through a packed column, and the pyrolysis oil was condensed by cooling water from a chiller (cooling water temperature at inlet $=10^{\circ} \mathrm{C}$ ). The pyrolysis oil was collected using an oil receiver at three reactor temperature ranges: $300-400{ }^{\circ} \mathrm{C}, 400-425^{\circ} \mathrm{C}$, and $425-450{ }^{\circ} \mathrm{C}$. Uncondensed gases were exhausted outside. The comparison of process specification between lab-scale and prototype are shown in Table 1.

Table 1. Specification of process conditions at lab-scale and prototype-scale.

\begin{tabular}{ccc}
\hline Specification & Lab-Scale & Prototype \\
\hline Feed & Batch & Semi-batch with melting step \\
Reactor volume & $1 \mathrm{~L}$ & $20 \mathrm{~L}$ \\
Heating rate & not control & $10^{\circ} \mathrm{C} / \mathrm{min}$ \\
Pressure & 0 bar gauge & 0.5 bar gauge \\
Nitrogen flow & Vacuum purge & Sweep purge $(1 \mathrm{NL} / \mathrm{min})$ \\
Cooling water & Ice bath & chiller $\left(15^{\circ} \mathrm{C}\right)$ \\
Heater & Heating mental & Heating band \\
Agitation & unstirred & stirred \\
\hline
\end{tabular}

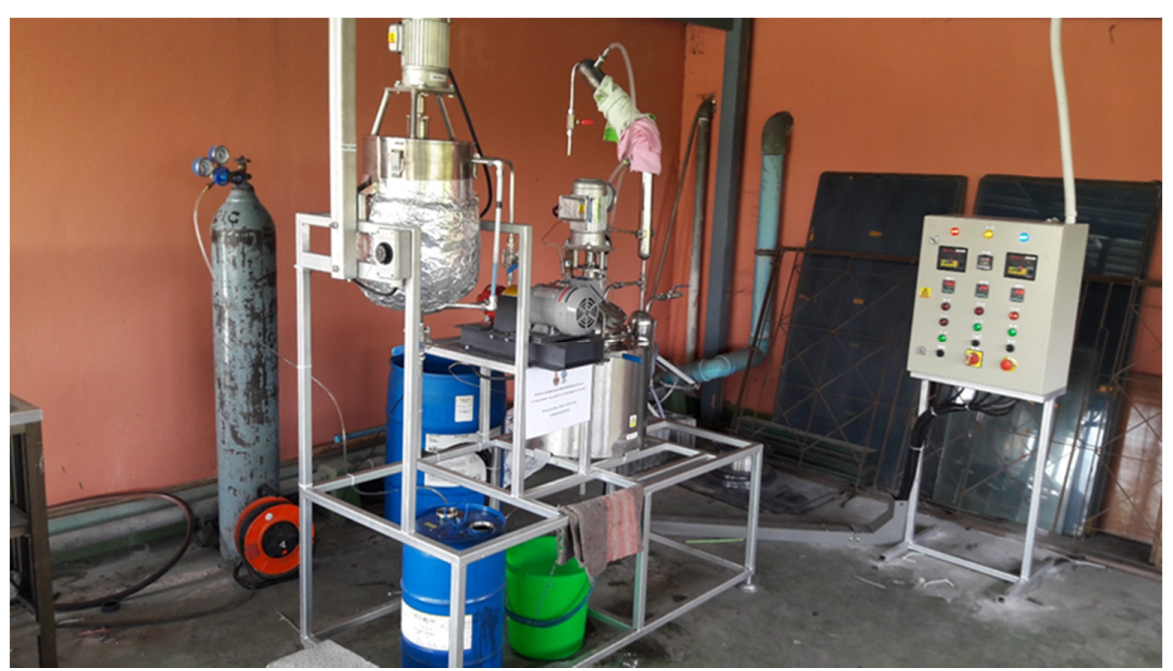

(a)

Figure 2. Cont. 


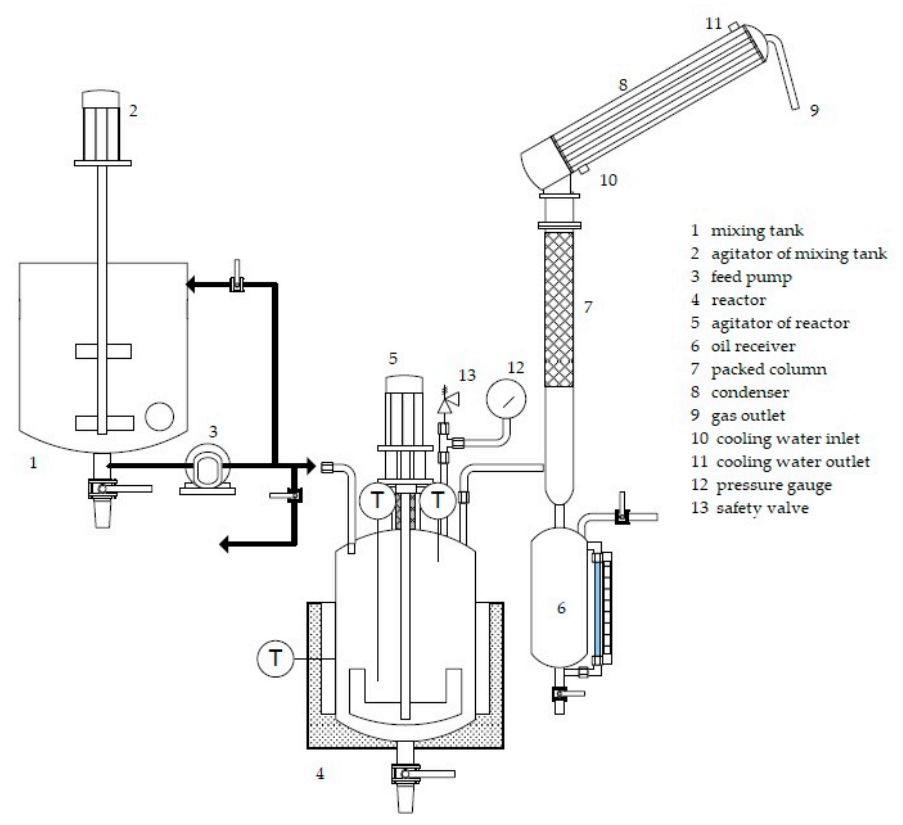

(b)

Figure 2. Co-pyrolysis prototype for a $10 \mathrm{~kg} /$ day process: (a) photograph of the prototype setup; (b) diagram of the prototype.

\subsection{Product Analysis}

The properties of the oil samples were tested as follows: the flash point (ASTM D 93) was determined using a Pensky Martens model HFP 380 (Walter Herzog GmbH, Lauda-Königshofen, Germany); the viscosity @ $40{ }^{\circ} \mathrm{C}$ (ASTM D 445) using a viscometer bath model TV2500B (PM Tamson Instruments, Bleiswijk, Netherlands); the colour measurement (ASTM D 1500-96) using a model Comparator 3000 series (Lovibond, Dortmund, Germany); the specific gravity (ASTM D1298) using a glass hydrometer; and the distillation temperature (ASTM D86) and cetane index (ASTM D 976-06) using an Automated Distillation Tester model AD-6 (TANAKA Scientific Limited, Tokyo, Japan). The pyrolysis oil flash point, specific gravity, distillation temperature at $90 \%$ recovery, cetane index (calculated from the density and temperature of distillation at $50 \%$ recovery), viscosity, and colour were compared with standards for diesel oil specified by the Department of Energy Business, Ministry of Energy of Thailand. The chemical composition of the hydrocarbon compounds of the pyrolytic oils was analysed using a gas chromatography and mass spectrometry analyser (GC-MS, QP2010, Shimadzu, Kyoto, Japan) with an HP-5 column $30 \mathrm{~m}$ in length and $0.25 \mathrm{~mm}$ in diameter, a 10:1 split, a Helium gas flowrate of $0.9 \mathrm{~mL} / \mathrm{min}$, and an oven temperature of $170{ }^{\circ} \mathrm{C}$ to $320^{\circ} \mathrm{C}\left(10^{\circ} \mathrm{C} / \mathrm{min}\right)$.

\section{Results and Discussion}

\subsection{Thermal Decomposition of the Raw Materials}

Figure 3 presents the thermogravimetric analysis (TGA) curve of each of the raw materials (used lubricant oil and waste plastics) used in the co-pyrolysis. The used lubricant oil decomposed in two steps: the first step occurred between $170{ }^{\circ} \mathrm{C}$ and $290^{\circ} \mathrm{C}$, while the second step occurred at nearly $400{ }^{\circ} \mathrm{C}$ [15]. HDPE, PS, and PP decomposed at $470-500{ }^{\circ} \mathrm{C}, 410-440{ }^{\circ} \mathrm{C}$ and $420-480{ }^{\circ} \mathrm{C}$, respectively. Thus, the observed thermal stabilities of the feedstocks followed the order HDPE $>$ PP $>$ PS $>$ used lubricant oil, in agreement with the TGA results reported in reference [18]. The co-pyrolysis mixture of used lubricant oil blended with mixed plastics (HDPE, PP, and PS) could be decomposed completely at $500{ }^{\circ} \mathrm{C}$. However, due to the limitations of the heating equipment that was used for the lab-scale pyrolysis, the final temperature of the co-pyrolysis experiments was set as $450{ }^{\circ} \mathrm{C}$. 


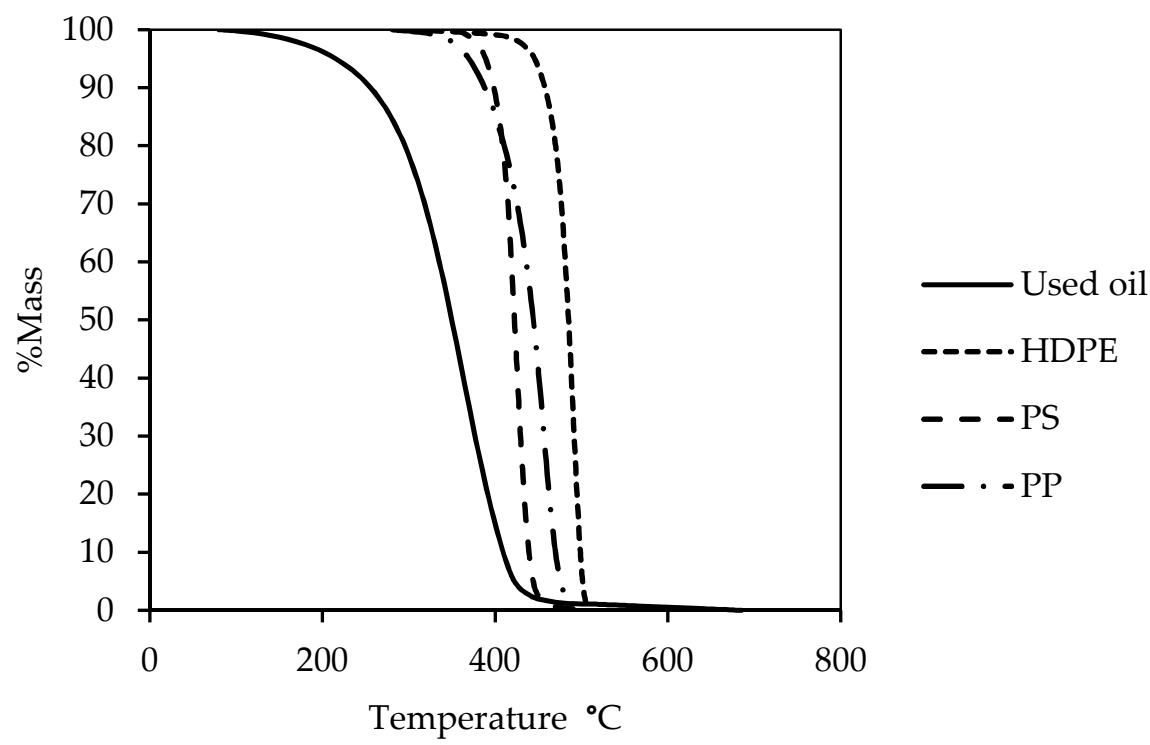

Figure 3. TGA analysis of the co-pyrolysis materials.

\subsection{Proximate and Ultimate Analyses of Raw Materials}

Carbon and hydrogen are main elements in the plastic waste and the used lubricant oil components with small amount of nitrogen, sulphur and oxygen which derived from their additives. Verification of the existence of hydrocarbons in raw materials can be determined from the $\mathrm{H} / \mathrm{C}$ ratios. The H/C ratio also indicate the level of saturation in the carbon-carbon bonds. In pyrolysis of oil, the decrease of $\mathrm{H} / \mathrm{C}$ ratio was observed which suggested that the dehydration and aromatization had occurred to form compounds containing carbon-carbon double bonds [19]. From Table 2, we have found that PP has the highest $\mathrm{H} / \mathrm{C}$ ratio, while PS show lowest $\mathrm{H} / \mathrm{C}$ ratio. The $\mathrm{H} / \mathrm{O}$ ratio of pyrolysis oil product was higher compared with the raw materials. Oil shows higher $\mathrm{H} / \mathrm{O}$ ratio than the plastic wastes. The $\mathrm{O} / \mathrm{C}$ ratio indicates the acidity of oil products. Low $\mathrm{O} / \mathrm{C}$ ratio compounds shows low acidity. The pyrolysis oil products show decreasing of $\mathrm{O} / \mathrm{C}$ ratio compared to the case using PS as raw materials.

Table 2. Feedstock characteristics.

\begin{tabular}{|c|c|c|c|c|c|c|c|c|c|c|}
\hline \multirow{2}{*}{ Feed } & \multicolumn{2}{|c|}{ Proximate Analysis (\%wt.) } & \multicolumn{8}{|c|}{ Ultimate Analysis (\%wt.) } \\
\hline & Volatile Matter & Ash & $\mathrm{C}$ & $\mathbf{H}$ & $\mathbf{N}$ & $S$ & $\mathbf{O}$ & $\mathrm{H} / \mathrm{C}$ & $\mathrm{H} / \mathrm{O}$ & $\mathrm{O} / \mathrm{C}$ \\
\hline HDPE [2] & 99.4 & 0.6 & 85.5 & 14.2 & 0.09 & 0.3 & 0.44 & 1.99 & 516.4 & 0.0039 \\
\hline PP [2] & 99.1 & 0.9 & 85.1 & 14.4 & 0.07 & 0.2 & 1.06 & 2.03 & 217.4 & 0.0093 \\
\hline PS [20] & 99.5 & 0.0 & 92.7 & 7.9 & 0 & 0 & 0 & 1.02 & 104.6 & 0.0108 \\
\hline Used oil [11] & 98.88 & 0.8 & 85.13 & 14.05 & 0.29 & 0.38 & 0.15 & 1.98 & 1498.7 & 0.0013 \\
\hline
\end{tabular}

\subsection{Properties of the Oil Products}

Four different ratios of waste lubricant oil and the three waste plastics were tested: 50:30:10:10, 50:30:20:0, 50:30:0:20, and 50:0:30:20 (Oil:HDPE:PP:PS, weight percent). In each experiment, the mixture was subjected to a final temperature of $450{ }^{\circ} \mathrm{C}$ for $4 \mathrm{~h}$. Table 3 shows the properties of the oil products, whereas Table 4 shows the product yields; the ratio 50:30:0:20 produced the highest oil yield. The products of all the experiments exhibited unsatisfactory flash point temperatures (lower than the standard of $52{ }^{\circ} \mathrm{C}$ ). A higher HDPE content relative to PP and PS may increase the flash point. The flash points of the pyrolysis oils obtained from PP and PS were lower than that of commercial diesel [21,22]. The specific gravity and colour of the products resulting from all of the tested ratios met the diesel standards. Previous research has reported the pyrolysis of a mixture of PE, PP and waste motor oil (WMO) at different blend ratio of 1:1:1, 1:1:2 and 1:1:4 by weight. The increase in the 
amount of WMO in all blends led to increase in both the viscosities and specific gravities of the liquid products. The flash point of all liquid products obtained from co-pyrolysis processes were lower than those of commercial diesel $\left(>55^{\circ} \mathrm{C}\right)$ [11]. The distillation temperature at $90 \%$ recovery and the cetane index are shown only for the ratio 50:30:20:0 ( $353^{\circ} \mathrm{C}$ and 65 , respectively). This is because when the oil samples were heated, due to the presence of polystyrene, some bubble overflow into the condenser of the distillation tester occurred, which also prevented determination of the cetane index. Both the cetane index and the diesel index have been used to evaluate the ignition quality of diesel fuel from HDPE and PP pyrolysis oils [23,24]; the cetane index of the pyrolysis oils of the PS pyrolysis oil was not detected. Therefore, the feedstock composition that did not include polystyrene as a raw material was selected for use in the $10 \mathrm{~kg} /$ day prototype, the results of which are shown in Table 4.

Table 3. Properties and product yields of pyrolytic oil for the waste oil blended with mixed plastic waste (lab-scale).

\begin{tabular}{|c|c|c|c|c|c|}
\hline \multirow{2}{*}{ Properties } & \multicolumn{4}{|c|}{ Oil:PE:PP:PS (\%wt.) } & \multirow{2}{*}{ Standard of Diesel * } \\
\hline & 50:30:10:10 & $50: 30: 20: 0$ & $50: 30: 0: 20$ & $50: 0: 30: 20$ & \\
\hline Flash point $\left({ }^{\circ} \mathrm{C}\right)$ & 29.25 & 29 & 28 & 28 & $>52$ \\
\hline Viscosity (cSt) @ $40^{\circ} \mathrm{C}$ & 1.76 & 1.98 & 2.20 & 2.25 & $1.8-4.1$ \\
\hline Specific gravity & 0.85 & 0.81 & 0.82 & 0.82 & $0.81-0.87$ \\
\hline Distillation ${ }^{\circ} \mathrm{C} @ 90 \%$ recovery & n.d. & 353 & n.d. & n.d. & $<357$ \\
\hline Colour & 2.0 & 2.5 & 2.0 & 2.0 & $<4.0$ \\
\hline Cetane index & n.d. & 65 & n.d. & n.d. & $>50$ \\
\hline
\end{tabular}

n.d. $=$ not detected. ${ }^{*}$ standard of diesel specified by the Department of Energy Business, Ministry of Energy of Thailand.

Table 4. Properties and product yields of the pyrolytic oil from the prototype (10 kg/day).

\begin{tabular}{cccccc}
\hline Properties & \multicolumn{3}{c}{ Prototype } & \multirow{2}{*}{ Lab-Scale } & Standard of Diesel \\
\cline { 2 - 4 } & $\mathbf{3 0 0 - 4 0 0}{ }^{\circ} \mathbf{C}$ & $\mathbf{4 0 0 - 4 2 5}{ }^{\circ} \mathbf{C}$ & $\mathbf{4 2 5 - 4 5 0}{ }^{\circ} \mathbf{C}$ & & $>52$ \\
Flash point $\left({ }^{\circ} \mathrm{C}\right)$ & 29 & 35 & 37 & 29 & $1.8-4.1$ \\
Viscosity (cSt) @ $40{ }^{\circ} \mathrm{C}$ & 2.02 & 3.71 & 5.84 & 1.98 & $0.81-0.87$ \\
Specific gravity & 0.81 & 0.82 & 0.82 & 0.81 & $<357$ \\
Distillation ${ }^{\circ} \mathrm{C} @ 90 \%$ recovery & 299 & 347 & 373 & 353 & $<4.0$ \\
Colour & 3.5 & 4.0 & 4.5 & 2.5 & $>50$ \\
Cetane index & 53 & 66 & 67 & 65 & \\
\hline
\end{tabular}

The product yields of the lab-scale and the scaled-up prototype pyrolysis are shown in Tables 5 and 6, respectively. The oil product yields of a lab-scale show that the effect of plastic waste type in a mixture with used lubricant oil are as follows: $\mathrm{PE} / \mathrm{PS}>\mathrm{PE} / \mathrm{PP} / \mathrm{PS}>\mathrm{PP} / \mathrm{PS}$, which are close to the PE/PP. The gas yields are as follows: PP/PS $>\mathrm{PE} / \mathrm{PP}>\mathrm{PE} / \mathrm{PP} / \mathrm{PS}>\mathrm{PE} / \mathrm{PS}$, and the solid yields are as follows: $\mathrm{PE} / \mathrm{PP}>\mathrm{PE} / \mathrm{PS}>\mathrm{PE} / \mathrm{PP} / \mathrm{PS}$. The trend of product yield is similar to those reported by Miandad et al. [25]. The prototype process provided the total oil yield of $68.86 \%$. Most of oil yields were produced at the temperature range of $400-425^{\circ} \mathrm{C}(31.64 \%)$ along with temperature range $425-450^{\circ} \mathrm{C}(22.87 \%)$, and $300-400{ }^{\circ} \mathrm{C}(14.35)$. The total oil yield and solid yield $(68.86 \%$ and $23.72 \%)$ of the prototype process were higher than the lab-scale oil and solid yields $(63.36 \%$ and $18.42 \%$, respectively). The higher yields may be due to higher heat transfer in the larger volume of the prototype reactor, which could accelerate $\mathrm{C}-\mathrm{C}$ bond cleavage. We propose a mechanism for the pyrolysis of long chain hydrocarbons as shown in Equations (1)-(4): 


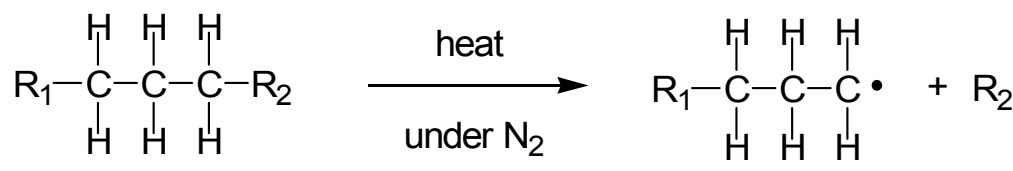<smiles>[R]CC(C)CC</smiles>

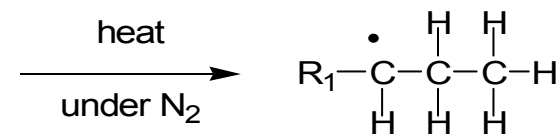<smiles>[R]C(C)C(C)C</smiles><smiles>[R][CH][CH+]C=C</smiles>

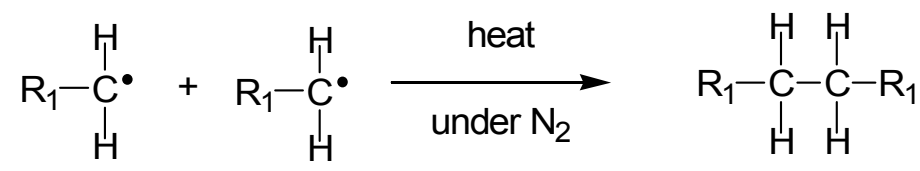

Table 5. Pyrolysis products yields for different used lubricant oil and plastic wastes (Lab-scale).

\begin{tabular}{ccccc}
\hline \multirow{2}{*}{ Products } & \multicolumn{4}{c}{ Yield (\%wt.) } \\
\cline { 2 - 5 } & $\mathbf{5 0 : 3 0 : 1 0 : 1 0}$ & $\mathbf{5 0 : 3 0 : 2 0 : 0}$ & $\mathbf{5 0 : 3 0 : 0 : 2 0}$ & $\mathbf{5 0 : 0 : 3 0 : 2 0}$ \\
\hline Oil & 73.41 & 63.36 & 84.58 & 55.54 \\
Solid residue & 14.80 & 18.42 & 5.88 & 16.35 \\
Gas & 11.79 & 18.22 & 9.54 & 28.11 \\
Total & 100 & 100 & 100 & 100 \\
\hline
\end{tabular}

Table 6. Pyrolysis products yields for different temperature range (Prototype).

\begin{tabular}{ccccc}
\hline Products & \multicolumn{3}{c}{ Yield (\%wt.) } & Lab Scale \\
\hline & $300-400{ }^{\circ} \mathrm{C}$ & $400-425{ }^{\circ} \mathrm{C}$ & $425-450{ }^{\circ} \mathrm{C}$ & $300-450{ }^{\circ} \mathrm{C}$ \\
Oil & 14.35 & 31.64 & 22.87 & 63.36 \\
Solid residue & $\longleftarrow$ & $23.72 \longrightarrow$ & 18.42 \\
Gas & $\longleftarrow$ & $\longrightarrow$ & 18.22 \\
Total & \multicolumn{5}{c}{100.00} & 100.00 \\
\hline
\end{tabular}

The first reaction in the mechanism is initiation by the thermal cleavage of the $\mathrm{C}-\mathrm{C}$ bond to produce a primary carbon free radical (Equation (1)), followed by isomerization to a more stable secondary carbon free radical (Equation (2)). Then, the cracking of the $C$ radical and the $C$ bond in Equation (3) produces a primary carbon free radical with a shorter chain length and an alkene compound, followed by the combination of two free radicals to produce a small molecule alkane (Equation (4)) [26].

The composition of the raw material mixture and prototype design affected the increasing of oil yield and a decreasing of gas yield because the feedstock fed to the reactor were in liquid phase (all raw materials were completely melted). The pyrolysis time used in prototype was $80 \mathrm{~min}\left(300-450{ }^{\circ} \mathrm{C}\right)$ which was shorter than in the lab-scale for $4 \mathrm{~h}$. The pyrolysis reaction time was not complete because of higher solid yield in the prototype $(23.72 \%)$ compared with the lab-scale $(18.42 \%)$.

The specific gravity values were similar to that obtained from the laboratory reactor, while the colour and viscosity differed. These results may be due to the better mixing achieved by the stirring and nitrogen gas flow in the prototype reactor. The oil yield was improved even at a lower temperature range. All the properties of the oil produced at the temperature range $400-425{ }^{\circ} \mathrm{C}$ were suitable for diesel oil except for the flash point temperature, which was lower than the standard for diesel. 
The pressure and flowrate of the carrier gas are important parameters for optimizing product yield and composition [15]. Therefore, comparing the operating conditions used for the lab-scale and prototype pyrolysis, the higher pressure ( 0.5 bar) and the nitrogen gas flow through the reactor improved the composition of the oil product at the prototype scale. Nitrogen gas is commonly used in pyrolysis processes and to produce oils with high olefin and paraffin contents $[27,28]$.

\subsection{Hydrocarbon Compounds}

The hydrocarbon compounds were analysed using a gas chromatography and mass spectrometry analyser. The pyrolytic oil contained more than 100 chemical components. Therefore, these components were grouped into four groups based on their structure: paraffin, olefin, cyclic, and aromatic compounds. The proportions of the four types of co-pyrolysis products as determined by GC-MS are shown in Table 7. The main component of standard diesel oil is paraffins. The oil product of the mixture with proportions of 50:30:20:0 showed the highest paraffin $(55.723 \%)$ content among the oil products, and was free of aromatic compounds because no PS was present in the raw materials. HDPE and PP are polyolefin plastics. Olefins and cyclic compounds were observed the products of the 50:30:20:0 mixture, possibly because the heating value in the reactor was not sufficient to break the carbon bonds of the raw materials.

Table 7. Hydrocarbon compounds in the product oils.

\begin{tabular}{cccccccc}
\hline \multicolumn{3}{c}{ Proportion \%wt. } & \multicolumn{4}{c}{$\%$ Hydrocarbon Compound } \\
\hline Oil & PE & PP & PS & Paraffins & Olefins & Cyclic & Aromatic \\
\hline 50 & 30 & 10 & 10 & 44.450 & 23.576 & 4.134 & 27.840 \\
50 & 30 & 20 & 0 & 55.723 & 35.363 & 8.914 & 0 \\
50 & 30 & 0 & 20 & 35.096 & 18.540 & 0 & 46.364 \\
50 & 0 & 30 & 20 & 10.365 & 6.897 & 14.523 & 68.215 \\
\hline
\end{tabular}

Siddiqui et al. studied the thermal pyrolysis of two kinds of plastic (LDPE, HDPE, PP and PET) mixed with PS. They had found that the oil products from the pyrolysis of PS contained in the mixture produced aromatic products dominated by styrene and styrene oligomers. Most aliphatic compounds in the oil were HDPE/PP/PS, followed by HDPE/PS and PP/PS while the oil product from PP/PS had the highest aromatic compound, followed by HDPE/PS and HDPE/PP/PS [29].

\subsection{Number of Carbon Atoms}

Another important parameter used to verify an oil product as diesel oil is the number of carbon atoms in the components of the oil products [28]. The analysis of the co-pyrolysis products is shown in Table 8. For this work, the number of carbon atoms was divided into three ranges: gasoline oil $\left(C_{6}-C_{12}\right)$, diesel oil $\left(C_{13}-C_{19}\right)$, and heavy oil $\left(>C_{20}\right)$. The percentage of products in the diesel oil range was greatest in the oil products from the 50:30:20:0 mixture (45.28\%); this mixture also showed low gasoline content. The results confirmed that the oil product of this mixture was a diesel-like fuel. The maximize diesel fuel fractions were studied using HDPE, the pyrolytic oil is very similar to diesel fuel, and contained mainly linear chain hydrocarbons distributed in the range $C_{10}-C_{38}$ [30]. Therefore, high proportion ratio of HDPE in the plastic blends is recommended for the production of diesel fuel.

Table 8. Proportion of compounds with different numbers of carbon atoms in the co-pyrolysis products.

\begin{tabular}{cccc}
\hline $\begin{array}{c}\text { Proportion (\%wt.) } \\
\text { Oil:PE:PP:PS }\end{array}$ & $\begin{array}{c}\text { \% Gasoline Oil } \\
\text { Compounds }\left(\mathbf{C}_{\mathbf{6}}-\mathbf{C}_{\mathbf{1 2}}\right)\end{array}$ & $\begin{array}{c}\text { \% Diesel Oil } \\
\text { Compounds }\left(\mathbf{C}_{\mathbf{1 3}}-\mathbf{C}_{\mathbf{1 9}}\right)\end{array}$ & $\begin{array}{c}\text { \% Heavy Oil } \\
\text { Compounds }\left(>\mathbf{C}_{\mathbf{2 0}}\right)\end{array}$ \\
\hline 50:30:10:10 & 38.64 & 38.61 & 22.75 \\
50:30:20:0 & 41.86 & 45.28 & 12.86 \\
50:30:0:20 & 54.96 & 36.46 & 8.58 \\
50:0:30:20 & 81.32 & 15.46 & 3.22 \\
\hline
\end{tabular}




\section{Conclusions}

The co-pyrolysis of waste oil blended with three types of plastic waste were carried out under nitrogen gas at atmospheric pressure on a lab-scale. The appropriate ratio of raw materials selected was 50:30:20:0 \%wt. by considering the properties of the oil products. The raw materials ratio that produced the oil with properties passing the standard for diesel fuels determined by the Ministry of Energy of Thailand was selected for further study using a pilot scale system. The analysis of the oil products revealed that the pyrolysis of waste oil blended with plastic waste without polystyrene contained high contents of paraffins $(55.723 \%)$, and the number of carbon atoms in the components of the oil product mainly fell within the diesel range $(45.28 \%)$.

The heat transfer limit in the pyrolysis of plastic waste process affects the reactor design. Agitation of the mixture results in better heat transfer. The potential of the waste plastics-lubricant oil co-pyrolysis are the simple design of reactor in form batch reactor with low speed agitation and low cost of construction. The prototype co-pyrolysis process exhibited good performance, producing diesel-like fuel with a higher yield (68.86 \%wt.) than the lab-scale process (63.36 \%wt.). Lower gases yield was obtained due to its higher pressure, the flow of the carrier gas through the stirred reactor, and raw materials feed in the homogenous phase from the melting tank.

Author Contributions: Conceptualization, N.P. and S.P.-A.; Methodology, N.P. and S.P.-A.; Writing-Original Draft Preparation, N.P.; Writing—Review \& Editing, S.P.-A.; Funding Acquisition, N.P. and S.P.-A.

Funding: This research was funded by National Research Council of Thailand grant number 2559A16503062.

Acknowledgments: National Research Council of Thailand financially supported the research. The facility and analytical equipment were supported by the Department of Chemical and Materials Engineering, Rajamangala University of Technology Thanyaburi, Thailand.

Conflicts of Interest: The authors declare no conflicts of interest.

\section{References}

1. Waste Problems. Available online: http://www.now26.tv/view/66104 (accessed on 18 April 2017).

2. Aboulkas, A.; Makayssi, T.; Bilali, L.; El Harfi, K.; Nadifiyine, M.; Benchanaa, M. Co-pyrolysis of oil shale and High density polyethylene: Structural characterization of oil. Fuel Process. Technol. 2012, 96, $203-208$. [CrossRef]

3. Permsubscul, A.; Vitidsant, T.; Damronglerd, S. Catalytic cracking reaction of used lubricant oil to liquid fuels catalyzed by Sulfated Zirconia. Korean J. Chem. Eng. 2007, 24, 37-43. [CrossRef]

4. Gómez-Rico, M.F.; Martín-Gullón, I.; Fullana, A.; Conesa, J.A.; Font, R. Pyrolysis and combustion kinetics and emissions of waste lube oils. J. Anal. Appl. Pyrolysis 2003, 68-69, 527-546. [CrossRef]

5. Bhaskar, T.; Uddin, M.A.; Muto, A.; Sakata, Y. Recycling of waste lubricant oil into chemical feedstock or fuel oil over supported iron oxide catalysts. Fuel 2004, 84, 9-15. [CrossRef]

6. Lam, S.S.; Russell, A.D.; Chase, H.A. Microwave pyrolysis, a novel process for recycling waste automotive engine oil. Energy 2010, 35, 2985-2991. [CrossRef]

7. Aguado, J.; Serrano, D.P.; Vicente, G.; Sanchez, N. Effect of decaline solvent on the thermal degradation of HDPE. J. Polym. Environ. 2006, 14, 375-384. [CrossRef]

8. Lopez, G.; Artetxe, M.; Amutio, M.; Bilbao, J.; Olazar, M. Thermochemical routes for the valorization of waste polyolefinic plastics to produce fuels and chemicals. A review. Renew. Sustain. Energy Rev. 2017, 73, 346-368. [CrossRef]

9. Kunwar, B.; Cheng, H.N.; Chandrashekaran, S.R.; Sharma, B.K. Plastics to fuel: A review. Renew. Sustain. Energy Rev. 2016, 54, 421-428. [CrossRef]

10. Serrano, D.P.; Aguado, J.; Escola, E.; Garagorri, E. Performance of a continuous screw kiln reactor for the thermal and catalytic conversion of polyethylene-lubricanting oil base mixtures. Appl. Catal. B Environ. 2003, 44, 95-105. [CrossRef]

11. Uçar, S.; Özkan, A.R.; Karagöz, S. Co-pyrolysis of waste polyolefins with waste motor oil. J. Anal. Appl. Pyrolysis 2016, 119, 233-241. 
12. Phetyim, N. Co-Pyrolysis technique between used lubricant oil and HDPE by activated zeolite catalyst. J. Eng. RMUTT 2015, 13, 75-84.

13. Phetyim, N.; Sirisangsawang, R.; Pornpichet, W.; Maiket, C. Co-Pyrolysis between used lubricant oil and polystyrene using activated zeolite catalyst. KKU Res. J. 2016, 16, 112-119.

14. Bartocci, P.; Bidini, G.; Asdrubali, F.; Beatrice, C. Batch pyrolysis of pellet made of biomass and crude glycerol: Mass and energy balance. Renew. Energy 2018, 124, 172-179. [CrossRef]

15. Breyer, S.; Mekhitarian, L.; Rimez, B. Production of an alternative fuel by the co-pyrolysis of landfill recovered plastic waste and lubrication oils. Waste Manag. 2017, 60, 363-374. [CrossRef] [PubMed]

16. Miskolczi, N.; Ateş, F. Thermo-catalytic co-pyrolysis of recovered heavy oil and municipal plastic wastes. J. Anal. Appl. Pyrolysis 2017, 128, 1-12. [CrossRef]

17. Kim, S.S.; Kim, J.; Jeon, J.K.; Park, Y.K.; Park, C.J. Non-isothermal pyrolysis of mixtures of waste automobile lubricant oil and polystyrene in a stirred batch reactor. Renew. Energy 2013, 54, 241-247. [CrossRef]

18. Sharuddin, S.D.A.; Abnisa, F.; Daud, W.M.A.W.; Aroua, M.K. A review on pyrolysis of plastic wastes. Energy Convers. Manag. 2016, 115, 308-326. [CrossRef]

19. Das, P.; Tiwari, P. The effect of slow pyrolysis on the conversion of packaging waste plastics (PE and PP) into fuel. Waste Manag. 2018, 79, 615-624. [CrossRef] [PubMed]

20. Kim, S.S.; Kim, S. Pyrolysis characteristics of polystyrene and polypropylene in a stirred batch reactor. Chem. Eng. J. 2004, 98, 53-60. [CrossRef]

21. Ahmad, I.; Khan, M.I.; Khan, H.; Ishaq, M.; Tariq, R.; Gul, K.; Ahmad, W. Pyrolysis study of polypropylene and polyethylene into premium oil products. Int. J. Green Energy 2014, 12, 663-671. [CrossRef]

22. Pinto, F.; Costa, P.; Gulyurtlu, I.; Cabrita, I. Pyrolysis of plastic wastes. 1. Effect of plastic waste composition on product yield. J. Anal. Appl. Pyrolysis 1998, 51, 39-55. [CrossRef]

23. Cookson, D.J.; Latten, J.L.; Shaw, I.M.; Smith, B.E. Property-composition relationships for diesel and kerosene fuels. Fuel 1984, 64, 509-519. [CrossRef]

24. Kumar, S.; Prakash, R.; Murugan, S.; Singh, R.K. Performance and emission analysis of blends of waste plastic oil obtained by catalytic pyrolysis of waste HDPE with diesel in a CI engine. Energy Convers. Manag. 2013, 74, 323-331. [CrossRef]

25. Miandad, R.; Barakat, M.A.; Aburiazaiza, A.S.; Rehan, M.; Ismail, I.M.I. Effect of plastic waste types on pyrolysis liquid oil. Int. Biodeterior. Biodegrad. 2017, 119, 239-252. [CrossRef]

26. Bradley, J.N. A general mechanism for the high-temperature pyrolysis of alkanes. The pyrolysis of isobutene. Proc. R. Soc. Lond. A 1974, 337, 199-216. [CrossRef]

27. Abbas-Abadi, M.S.; Haghighi, M.N.; Yeganeh, H.; McDonald, A.G. Evaluation of pyrolysis process parameters on polypropylene degradation products. J. Anal. Appl. Pyrolysis 2014, 109, 272-277. [CrossRef]

28. Siddiqui, M.N.; Redhwi, H.H. Pyrolysis of mixed plastics for the recovery of useful products. Fuel Process. Technol. 2009, 90, 545-552. [CrossRef]

29. Sheirs, J.; Kaminsky, W. Feedstock Recycling and Pyrolysis of Waste Plastics: Converting Plastics into Diesel and Other Fuels; John Wiley \& Sons: London, UK, 2006; pp. 315-344.

30. Joppert, N., Jr.; da Silva, A.A.; da Costa Marques, M.R. Enhanced diesel fuel fraction from waste high-density polyethylene and heavy gas oil pyrolysis using factorial design methodology. Waste Manag. 2015, 36, 166-176. [CrossRef] [PubMed]

(C) 2018 by the authors. Licensee MDPI, Basel, Switzerland. This article is an open access article distributed under the terms and conditions of the Creative Commons Attribution (CC BY) license (http://creativecommons.org/licenses/by/4.0/). 